\title{
MORTE E MODERNIDADEEM FRANZ KAFKA E WALTER BENJAMIN.
}

Flávio Valentim de Oliveira*

\begin{abstract}
RESUMO
Kafka nos mostra que na modernidade a morte foi expulsa do espaço interior que reunia ao mesmo tempo a autoridade soberana e o "caráter de solenidade pública". Sem nenhuma luz interior, digamos assim, o personagem do conto póstumo intitulado Ocaçador Graco mostra a morte dentro de um espaço depurado, expulsa de qualquer tipo de psicologização religiosa ou de qualquer caráter pedagógico, pois se a morte tinha ainda uma vinculação com a "transcendência" - morrer sabiamente, por exemplo, - em Graco, encontramos a ausência total de sabedoria.Já para Benjamin, o burguês é descrito no livro das Passagens, especificamente no caderno $I$, como aquele que de todo não aboliu a velha concepção medieval da "fortificação". Essa antiga arquitetura que serviu de proteção contra o mundo exterior adquiriu formas de "compartimento"; onde as mobílias, em particular, se transformaram em um mundo "habitável". Mas as mobílias evocam um passado ainda mais primitivo, a realidade "totêmica" da relação do homem com os seus objetos. No caso do burguês, a mobília é um totem protetor contra a morte. Neste aspecto, o interior foi um estilo, a máscara social burguesa no século XIX contra a morte.
\end{abstract}

Palavras-chave:morte; modernidade; Kafka; transcendência; subjetividade burguesa.

\section{DEATHANDMODERNITYINFRANZKAFKAANDWALTERBENJAMIN.}

\begin{abstract}
Kafka shows us that the modern death was expelled from the interior space while meeting the sovereign authority and the "character of public ceremony." No light inside, so to speak, the character of the tale entitled The Posthumous Graco hunter shows death inside a screened room, expelled from any religious or any psychologizing pedagogical character, as if death was still a link with the " transcendence "- die wisely, for example in Graco, we find the total lack of wisdom. As for Benjamin, the bourgeois is described in the book of tickets, particularly in the notebook I like that they all did not abolish the old medieval concept of "fortification." This former architecture that served as protection from the outside world acquired forms of "compartment" where the furnishings, in particular, became a world "habitable. But the furnishings evoke a more primitive past, the reality "totem" of man's relationship with their objects. In the case of the bourgeois, the furniture is a totem shield against death. In this respect, the interior was style, the social mask in the nineteenth century bourgeois against death.
\end{abstract}

Keywords:death;modernity;Kafka; transcendence; bourgeois subjectivity.

\footnotetext{
*Mestre em Filosofia pela UNICAMP/SP e Professor da Universidade da Amazônia (UNAMA)
} 
O conto intitulado Ocaçador Graco (Der JägerGracchus) ${ }^{1}$ é um texto póstumo de Kafka e pertence ao conjunto de suas pequenas narrativas que vieram alume somente no ano de 1931, quando então foram editadas por Max Brod sob o título Durante a construção da muralha da China. Narrativas não-impressas e prosa do espólio. ${ }^{2}$ Este conto póstumo trata justamente de um morto que não sabe mais o significado do que é morrer; por isso ele é um morto que "também vive", pois, segundo as palavras do próprio personagem Graco, seu "barco fúnebre errou o caminho."3 É a errância de um morto que não sabe absolutamente nada sobre o significado das velhas "artes de bem morrer". 4

O caçador Graco é literalmente um "morto vivo", mas não no sentido de um morto "considerado como mau e perigoso" como então se acreditava na Idade Média e, sim, de um morto que nada compreende sobre os assuntos do "além da morte", de um morto que não sabe repousar.

O problema é que sem o "além" enquanto direito de estabelecer relações com os vivos (principalmente porque o "além" era a esperança de um dia encontrar os "queridos mortos"6), a morte perde seu status público nas sociedades modernas, pois "num sentido radical”, os mortos "não são mais nada". ${ }^{7}$

Mesmo sem ter, digamos, uma passagem para o "além", a primeira imagem do conto mostra que ainda assim o caçador Graco é um viajante acompanhado de seu "barqueiro" e de dois ajudantes de "casacos escuros e botões de prata", onde todos são

\footnotetext{
${ }^{1}$ KAFKA, F., Der Jäger Gracchus, em: GesammelteWerke, Fischer TaschenbuchVerlag, Frankfurt am Main, 1983, pp. 75-79. Ver tradução de Modesto Carone, "O caçador Graco", em: Narrativas do espólio (São Paulo, Companhia das Letras, 2002), pp 66-72. Salvo indicações, em contrário, seguiremos a tradução de Carone, doravante citada como Graco.

${ }^{2}$ Max Brod é o responsável não apenas pela seleção e publicação das chamadas Narrativas do espólio como também pela escolha, em "grande parte", dos títulos desta obra póstuma de Kafka. Ver a este respeito o posfácio de Modesto Carone intitulado "Um espólio de alto valor", Op.cit, p. 219.

${ }^{3}$ Graco, p.69-70.

${ }^{4}$ Como bem mostra o historiador francês Philippe Ariès, trata-se das chamadas artes moriendi, situada historicamente na Idade Média, em que o moribundo era capaz de rever "sua vida inteira no momento em que morre" e de atribuir a morte um "caráter dramático"; um ritual "coletivo" com "carga de emoção" muito forte; onde o moribundo se torna o narrador escatológico de si mesmo e o protagonista da arte do "bem morrer". Cf. ARIÈS, Philippe. História da morte no Ocidente; tradução: Priscila Viana de Siqueira. Rio de Janeiro: Ediouro, 2003, p. 53.

${ }^{5} \mathrm{Na}$ realidade, não sabemos se Kafka conhecia ou não essa concepção do "morto vivo". Mas, segundo o historiador alemão Otto Gerhard Oexle em seu artigo intitulado A presença dos mortos, o "morto vivo" era uma figura tipicamente germânico-medieval que se manifestava no "culto popular aos mortos" e infundia medo e costumes de "proteção". Cf. OEXLE, Otto Gehrard. "A presença dos mortos", em: BRAET, Herman; VERBEKE, Werner. A morte na Idade Média; tradução: H. Megale, Yara F. Vieira e Maria C. Cescato. São Paulo: Edusp, 1996, p. 61.

${ }^{6}$ Cf. OEXLE, Otto Gehrard, p.31.

${ }^{7}$ OEXLE, p. 29.
} 
"recém-chegados" (Ankömmlinge $)^{8}$ na barca mortuária que aporta no "pequeno porto" de uma cidade. ${ }^{9}$ É importante ressaltar que Graco é um tipo arcaico de marinheiro, cuja viagem é de "mil e quinhentos anos". Embora a figura do navegante seja emblemática de um passado que estabelecia um nexo entre morte, narração e sabedoria, o caçador Graco não consegue se prestar como "intérprete entre os antigos e os modernos". ${ }^{10}$

É preciso reconhecer que esta imagem de Graco como morto viajante nos remete a uma antiga narrativa, especialmente os cantos X e XI da Odisséia (texto que Kafka sempre lia, admirava e até mesmo reescrevia, ao seu modo, algumas dessas narrativas). Nestes dois cantos lemos sobre a descida de Ulisses aos infernos, uma viagem empreendida não exatamente para fortalecer a crença do viajante na imortalidade, pois o próprio encontro de Ulisses com os mortos acontece numa geografia precária e tenebrosa: um fosso cavado pelo próprio herói como local onde se deve sacrificar o negro sangue de uma ovelha para então poder consultar o adivinho Tirésias, um fosso, diga-se de passagem, sempre cercado pelas sedentas sombras dos mortos. ${ }^{11}$ Sem dúvida, é uma visão decepcionante para as "nossas expectativas cristãs e platonistas de uma descrição do além" como bem analisa Gagnebin. ${ }^{12}$

Mas é no canto XI que encontramos uma imagem muito forte do mundo subterrâneo: a alma que primeiro Ulisses encontra é a de seu companheiro Elpenor. ${ }^{13}$ Este, por sua vez, reivindica seus rituais funerários que é, primeiramente, uma sepultura

\footnotetext{
${ }^{8} \mathrm{O}$ substantivo alemão Ankömmlinge ("recém-chegados") é algo essencialmente problemático no universo kafkiano. Seja na "aldeia" ou no "castelo" (como no caso do agrimensor $K$., personagem do romance $O$ castelo), seja no cais de uma cidade (como um morto chamado caçador Graco com sua barca mortuária), todos os "recém-chegados" são estrangeiros para Kafka, pois não habitam nenhum mundo, não entendem de costumes, de moral e tampouco devem ser considerados "filhos da sociedade". Cf. ANDERS, Günter. Kafka: pró e contra; tradução: Modesto Carone. São Paulo: Cosac Naify, 2007, pp. 35-38. A questão dos "recém-chegados" se transformou numa categoria de interpretação importante para uma geração de escritores alemães que aprendeu a ler Kafka no exílio por causa da ascensão do nazismo ao poder. Este é o caso de Günter Anders que então morava nos Estados Unidos.

${ }^{9}$ Graco, p. 66.

${ }^{10}$ Cf. Fragment zumJäger Gracchus, em: GesammelteWerke, Fischer TaschenbuchVerlag, Frankfurt amMain, 1983, pp. 248-249. Ver também "Fragmento para o caçador Gracchus"; tradução: Torrieri Guimarães, em: A muralha da China. Belo Horizonte: Itatiaia, 2000. pp. 242-243.

${ }^{11}$ HOMERO, Odisséia; tradução: Antônio Pinto de Carvalho. São Paulo: Nova Cultural, 2003, p. 139. Nas palavras da deusa Circe, o adivinho Tirésias, mesmo morto, é o único que tem o "dom de predizer"; os outros mortos são apenas "sombras que esvoaçam".

${ }^{12}$ GAGNEBIN, J.M. "A memória dos mortais: notas para uma definição de cultura a partir de uma leitura da Odisséia”, em: Lembrar, escrever, esquecer. São Paulo: Editora 34, 2006, p.26.

${ }^{13}$ Elpenor é aquele que teve uma morte banal por causa do "excesso de vinho", pois quando se encontrava no telhado de Circe quis descer e optou pelo caminho direto (a imprudência), ao invés de descer pela escadaria, precipitou-se no solo e quebrou as "vértebras do pescoço". HOMERO, Odisséia, pp.143-144. Esta cena da morte banal aparece também no caçador Graco quando relata sobre o motivo de sua morte, sua queda "de um penhasco quando perseguia uma camurça". Graco, p. 69.
} 
para que seu "corpo" não fique "sem lágrimas" e, sobretudo, o pedido para que Ulisses crave sobre seu túmulo o "remo" que o viajante em vida "remava" com seus "companheiros". 14

Túmulo e lágrimas, eis o que Elpenor reivindica para que seus companheiros não esqueçam de sua imagem de "viajante". Neste episódio homérico, não ter o rito de memória fúnebre é uma desonra, pois é justamente a memória que lhe dá o direito do ritual de viagem, "de sorte que" - palavras de Elpenor - "os vindouros se recordem deste infeliz". ${ }^{15}$ Esta expressão de Elpenor só faz sentido se pensarmos nos rituais gregos da morte como uma "evocação dos ausentes", como "lamentação coletiva", enfim, da evocação dos companheiros mortos como acontecimento que permite inclusive aos vivos de reencontrar a sua própria "coragem" para seguir viagem. ${ }^{16}$ Por isso a importância poética e ética do canto de Ulisses, pois ele é o herói "que sabe lembrar, para os vivos, os mortos". ${ }^{17}$

Essa imagem do morto como viajante nos faz lembrar de uma outra antiga crença no "além" que podemos também encontrar na Idade Média, segundo a qual o destino dessa viagem tinha um lugar: o refrigério (anapsikseos) - "lugar da consolação e do descanso". 18 Essa antiga concepção do "além-túmulo" não se desenvolveu, entretanto, de um modo pacífico na consciência cristã. A tradição Escolástica tratou logo de apagá-la das mentalidades dos homens medievais, pois as "noções de espera, de descanso, lhes eram, com efeito, mais familiares do que as de ressurreição". ${ }^{19}$ Assim, do ponto de vista histórico-religioso, a temática do além assumiu um ponto de tensão entre as vertentes canônicas e heréticas no cristianismo no que diz respeito, sobretudo, à concepção das moradas das almas. Essa "geografia imaginária do além”, não deixa de revelar a própria relação da morte com o poder, principalmente, o poder espiritual sobre as almas. Essa diferença de concepções irá opor, inclusive, Santo Ambrósio de Santo Agostinho, para quem a morte é vista segundo a noção de "espera" e "glória", ao invés,

\footnotetext{
${ }^{14}$ HOMERO, Odisséia, p.143.

${ }^{15}$ HOMERO, p. 144.

${ }^{16}$ Cf. SIMONDON, M. Mémoire et oubli dans la pensée grecque. Paris: C.R.E.L-France,1982, pp.31-32. Ver principalmente a importância dos mortos para a formação de uma "memória da coragem"nas narrativas homéricas.

${ }^{17}$ GAGNEBIN, J.M. Op. cit., p. 27.

${ }^{18}$ ARIÈS, Philippe. "Uma antiga concepção do além”, em: BRAET, Herman; VERBEKE, Werner. A morte na Idade Média; tradução: Heitor Megale, Yara F. Vieira e Maria C. Cescato. São Paulo: Edusp, 1996. p.79.

${ }^{19}$ ARIËS, Philippe, p. 80.
} 
das noções de "condenação" e "punição", o que certamente, causava um desconforto no pensamento cristão esclarecido. ${ }^{20}$

Se o morto é um viajante para o além então é digno adornar o caixão e reconhecer o "luto" como sua última exposição social no mundo dos vivos e como a manifestação "legítima" e "necessária" da "dor por excelência". ${ }^{21}$ No caso do caçador Graco, essa "adornação"do caixão é assim descrita pelo narrador kafkiano: "era evidente que jazia um ser humano, debaixo de um grande tecido de seda estampado de flores e provido de franjas". ${ }^{22}$ Kafka parece parodiar essas antigas concepções do além. A paródia tem aqui o sentido de fazer novos experimentos, embora muitas vezes o resultado deste experimento seja mesmo a negatividade, a caricatura e o humor. ${ }^{23}$ Ora, o que realmente chama atenção nesta narrativa é o modo cômico da utilização dos adornos femininos, tais como: "tecido de seda", "flores" e "franjas" para falar de um morto.

Podemos comentar esta questão a partir de uma observação filológica: o termo alemão blumengemusterten ("estampado de flores") tem a função de oferecer um olhar agradável e simpático sobre o morto, serve para realçar, ainda que de modo risível, uma visão reconfortante da morte, pois está intimamente associado neste contexto, a um outro termo alemão que é o adjetivo gemütlich (que significa "acolhedor", "aconchegante"). ${ }^{24}$ É um ato irônico de feminização ou de "adornação"25 da morte que tem a finalidade inútil de provocar "emoções sublimes" no público.

\footnotetext{
${ }^{20}$ ARIÈS, p. 80.

${ }^{21}$ Em relação ao luto como última exposição social do morto, seguimos aqui novamente o estudo do historiador francês Philippe Ariès, que descreve o "luto" como a "expressão mais violenta dos sentimentos mais espontâneos". Cf. ARIÈS, P., História da morte no Ocidente; tradução: Priscila V. de Siqueira. Rio de Janeiro: Ediouro, 2003, p. 245.

${ }^{22}$ Graco, p. 66.

${ }^{23}$ No que diz respeito à paródia como experimento literário, podemos pensar aqui numa aproximação estilística entre Nietzsche e Kafka. Se Nietzsche e Kafka usam a paródia para não levar "nada a sério" é porque necessitam do humor, do lúdico e da jovialidade para não se filiarem a qualquer "seriedade" dogmática do pensamento. Sobre a importância da paródia em Nietzsche, ver JÚNIOR, Oswaldo Giacóia. Nietzsche \& Para Além do Bem e do Mal.Rio de Janeiro: Jorge Zahar, 2005, p.9,42.

${ }^{24}$ Graco, p. 66.

${ }^{25} \mathrm{O}$ historiador alemão Otto Gerhard Oexle menciona em seu artigo intitulado A presença dos mortos, que essa adornação da morte ou essa preocupação com a "sensibilidade" para a morte é feita na cultura alemã, não por acaso, pela personagem feminina do romance As Afinidades Eletivas (1809) de Goethe, chamada Charlotte, uma dama da "aristocracia rural" que irá reformar o "cemitério da igreja do povoado" com o firme propósito de transformar as sepulturas num espaço decorado, de "aparência tão agradável" e com "aspecto digno e sereno" que, aqueles que visitassem seus mortos, se sentiriam como que passeando com intenso prazer nesse novo e "colorido" espaço da morte.Cf. OEXLE, Otto Gehrard. "A presença dos mortos”, em: BRAET, Herman; VERBEKE, Werner. A morte na Idade Média; tradução: Heitor Megale, Yara F. Vieira e Maria C. Cescato. São Paulo: Edusp, 1996, pp. 30-31.
} 
Esta cena também evoca a antiga afinidade entre um morto e um ator. Talvez, por isso, Walter Benjamin observou, já no contexto moderno, que "o abismo que separa os atores do público" não é tão diferente do "abismo" em que "os mortos são separados dos vivos". Para Benjamin, esta separação entre "atores" e "público" e entre "mortos" e "vivos" se deve, principalmente, ao fato de que a "origem sagrada" tanto do palco teatral quanto do espetáculo da morte "perdeu sua função"social. ${ }^{26}$

A antiga função social que caracterizava a morte como ritual coletivo podia ser traduzida pelo processo de feminização do culto aos mortos. É este fenômeno histórico e literário que o historiador francês Philippe Ariès analisa de modo emblemático quando ressalta que até mesmo os "mais bravos guerreiros" e os "mais ilustres soberanos" medievais não recalcavam as suas emoções espontâneas de "dor" e de "luto" quando choravam como "mulheres histéricas" 27 diante dos corpos de amigos ou parentes e com os gestos mais variados, tais como: batidas no peito, esfolamentos do rosto, gritos, desmaios e até mesmo o caráter dramático das "vestes destroçadas", dos "abraços demorados" e beijos "apaixonados em cadáveres já frios". ${ }^{28}$

Este estudo histórico revela ainda que havia também um costume antigo na época romântica, praticado por mulheres (num misto de enfermeiras e maquiadoras), que consistia em oferecer seus serviços como "os últimos cuidados" com o morto; na tarefa de libertar a beleza do "rosto humano" das "impurezas da agonia", com o propósito de fixar a imagem do "belo cadáver". O morto com esse ritual, chamado de "toalete fúnebre" era contemplado como um "quase-vivo", dentro da perspectiva de "mascarar as aparências da morte e de conservar no corpo os ares familiares e alegres da vida". 29

Contudo, o "estampado de flores" (blumengemusterten) com que o caçador Graco está envolvido é uma ironia social e parece antecipar as próprias constatações históricas de Ariès sobre a mudança das atitudes do homem moderno em relação à morte, mudança esta que podemos chamar de "a recusa do luto", isto é, o gesto da

\footnotetext{
${ }^{26}$ BENJAMIN, Walter. "Que é o teatro épico? Um estudo sobre Brecht?", em: Magia e técnica, arte e política; tradução: Sérgio Paulo Rouanet. Obras escolhidas, v. 1, São Paulo: Brasiliense, 1985, p.78. No texto original em alemão, Walter Benjamin utiliza insistentemente o substantivo alemão Abgrund (abismo) para constatar que não existe mais um "palco" (Bühne) onde possa o ator e o morto produzir no público algum sentimento de "êxtase" (Rausch). Ver o ensaioWasist das Epische Theater? EineStudiezu Brecht, em: GesammelteSchriften II-2, Frankfurt am Main, SuhrkampVerlag, p. 519.

${ }^{27}$ Cf. ARIÈS, Philippe. História da morte no Ocidente; tradução: Priscila Viana de Siqueira. Rio de Janeiro: Ediouro, 2003, p. 245.

${ }^{28}$ ARIÈS, pp. 245-246.

${ }^{29}$ ARIÈS, pp.253-255.
} 
sociedade moderna que "proíbe aos vivos de parecerem comovidos", de uma recusa aos mortos para que deixem de "perturbar os vivos". 30

De maneira ainda mais trágica, o luto foi sendo substituído pela figura do "exterminador industrializado", tão cruel e complexo, que era capaz de adornar o espaço da morte com objetos requintados, expondo aos olhos humanos o fato de que "horror" e "conforto" poderiam habitar o mesmo espaço de destruição. Segundo Anders, todos “nós estamos a par dos 'aposentos sociais' que os chefes de campos de extermínio mobiliaram com estofados, vitrolas e quebra-luzes, parede-meia com as câmaras de gás". "Esse fenômeno Anders classificou de "a trivialidade do grotesco" - o que em larga medida deu a Kafka o título de fabulista de um mundo moderno "aterrorizante" justamente pelo fato de que o horror já não espantaria ninguém.

Mas convém ainda explicitar o termo feminização da morte em Kafka. No século XIX, quando a religião começou a manifestar sinais profundos de "decadência", no que diz respeito principalmente à concepção da morte como comunhão com a transcendência, o cultivo da "compaixão" se transformou numa espécie de substituto religioso, ela mesma se "religiosificou" quando a "autodissolução" e a "piedade" se transformaram na própria crença dos indivíduos na "redenção". ${ }^{32} \mathrm{~A}$ compaixão se transformou no êxtase da "pré-vida" por excelência das religiões, no estágio de preparação para uma vida mais verdadeira. ${ }^{33}$ A questão é que para Kafka o "ente feminino" não tem relação nenhuma com o mundo metafísico e a compaixão enquanto feminização da morte "não se acende em nome de qualidades positivas do seu objeto, mas à vista justamente dos seus defeitos, é, por assim dizer, um amor ao defeito à primeira vista". 34

Ora, o que fundamenta a compaixão como sistema metafísico é a sua compreensão de que a morte não é simplesmente uma "visão física absoluta" (o que acarretaria no interior do homem um hedonismo selvagem e corrompido) ou uma “consciência natural" de seu temor, já que na "linguagem da natureza, a morte significa aniquilação". Porém, em paralelo a essas duas concepções, resta ainda no homem a

\footnotetext{
${ }^{30}$ ARIÈS, p. 245.

${ }^{31}$ ANDERS, G. Op. cit, p.22.

${ }^{32}$ ANDERS, G, p. 41. O ensaio de Anders (esboçado já na década de 30) se inscreve na crítica às interpretações religiosas de Kafka como "santo" e também estão endereçadas a Max Brod (que, por sua vez, não suportava o livro de Anders por causa do conteúdo ateísta).

${ }^{33}$ ANDERS, G, p. 46.

${ }^{34}$ ANDERS, G, p. 42.
} 
"angústia da morte". Essa angústia nos dá acesso ao entendimento de que a morte enquanto sofrimento e "perigo de vida do outro" pode se transformar em algo arrebatador (um espetáculo que pede nossa participação) e que nos conduz a "compaixão" (Mitleid). ${ }^{36}$

O paradoxo do conto o caçador Graco é que ele é um personagem que está ambientado em uma cidade de espectadores desinteressados, de habitantes que não apresentam nenhum apego metafísico à morte, de audição petrificada, como se uma nova Górgona, agora dotada também do poder da fala, ali tivesse passado e endurecido o dom de ouvir desses habitantes, dando a cada um apenas um estado aterrorizante de paralisia e de mortificação histórica. Citemos Kafka: No cais ninguém prestou atenção nos recém-chegados, mesmo quando eles depositaram o ataúde
para aguardar o barqueiro, que ainda manipulava os cabos; ninguém se aproximou, ninguém
perguntou nada a eles, ninguém os olhou mais detidamente. ${ }^{37}$

Para Günter Anders, esses cenários kafkianos não advêm de nenhuma doutrina metafísica, uma vez que "é essa petrificação que empresta beleza ao mundo kafkiano".Essa beleza que seduz e petrifica é a "beleza da Medusa". ${ }^{38}$ Assim, as narrativas kafkianas, principalmente aquelas que tratam de "coisas sem vida", nos permitem “elaborar o 'reluzir' (Gleissen) da beleza a partir do 'esbugalhar de olhos' (Glotzen) do terrível".39

Neste aspecto, Anders aproxima a concepção de beleza kafkiana com o espírito dos gregos em relação as suas atitudes diante da "figura ultra-antiga e atroz" da Medusa. Essa aproximação pode ser esclarecida com uma advertência para todo e qualquer contemplador: a arte é aquilo que nos assusta, que nos mantém a distância, por isso mesmo é que a beleza de Medusa se fundamenta no que é " "terrivelmente belo",. 40

Mas, apesar de tudo, um homem aparece no conto com uma "tarja de luto" (Trauerband) para cumprir o papel solitário de anfitrião do morto. Nesta cena é possível

\footnotetext{
${ }^{35}$ Cf. SCHOPENHAUER, Arthur. Metafísica da morte; tradução: Jair Barboza. São Paulo: Martins Fontes, 2004, p. 59-60.

${ }^{36}$ SCHOPENHAUER, pp. 61-63. Se a maior angústia do homem "é a angústia da morte",a compaixão nos ensina o ato de desvencilhamento da morte da noção do "mal". Por isso, Schopenhauer cita a doutrina hinduísta que atribui ao "deus da morte" (Yama) dois semblantes: a imagem da morte como "temível" e "terrível" e a imagem "alegre" e "benévola".

${ }^{37}$ Graco, p.66.

${ }^{38}$ ANDERS, G. Op.ci, p.77.

${ }^{39}$ ANDERS, p. 78.

${ }^{40}$ ANDERS, pp. 77-78.
} 
observar, pela única vez na narrativa, um indivíduo "enlutado". Todavia, a cena do luto continua sendo algo perturbador, pois ela não é propriamente a cena de "reação à perda de uma pessoa amada". ${ }^{40}$ O caçador Graco não está na condição da "pessoa amada" que se foi. Isso, entretanto, não invalida a conceituação dada por Freud ao luto que é interessante aqui mencionar. O luto pode se manifestar como a reação à perda de "natureza mais ideal". ${ }^{41}$ No caso do caçador Graco, a perda está relacionada à idealidade da morte: a perda de seus laços com o reino da transcendência e, a transcendência de um morto (como "pessoa amada") nunca deixou de ser uma crença reparadora, um estado de abstração diante do sentimento de que o "mundo tornou-se pobre e vazio". 42

Para ir de encontro ao morto, este homem com sua tarja de luto precisa descer "por uma das ruazinhas estreitas, fortemente inclinadas, que davam para o porto". Esta passagem, de modo anedótico, narra o fato de que desagrada muito a este homem enlutado descer por estas ruazinhas "fortemente inclinadas" (starkabfallenden) ${ }^{43} \mathrm{O}$ que desagrada profundamente este homem de "tarja preta" é que ele é o prefeito da pequena cidade de Riva e sua presença no velório não se baseia em sentimentos espontâneos, mas apenas porque a morte se torna um problema administrativo.

\footnotetext{
Um homem de cartola e tarja de luto desceu por uma das ruazinhas estreitas, fortemente inclinadas, que davam para o porto. Olhou em torno com atenção; tudo o preocupava; a visão de sujeira num canto o fez contorcer o rosto. ${ }^{44}$
}

Não podemos perder de vista nesta passagem que o verbo alemão abfallen (que significa "estar em declive")nos remete também ao substantivo Abfall (que significa "lixo"). Esta constatação filológica se intensifica ainda mais no texto kafkiano quando o narrador destaca o seguinte gesto deste homem: "a visão de sujeira num canto o fez contorcer o rosto". ${ }^{45}$ Esse gesto de "contorcer o rosto" (das Gesichtverzerren) caracteriza uma atitude diante da morte. Mas qual o significado desta atitude no conto?

Para responder a esta indagação, é interessante recorrermos a um outro grande leitor de Kafka: Theodor Adorno. No ensaio Anotações sobre Kafka (1953), Adorno

\footnotetext{
${ }^{40}$ FREUD, S. Luto e melancolia; tradução: Luiz Alberto Hanns [et al] Rio de Janeiro. Imago, 2006, p. 103.

${ }^{41}$ FREUD,p. 103.

${ }^{42}$ FREUD, p. 105.

${ }^{43}$ Graco, p. 67

${ }^{44}$ Graco, p. 67.

${ }^{45}$ Graco, p. 67.
} 
argumenta que a narrativa de Kafka é "montada a partir do entulho" (Abfallsprodukten).Ele adere à sua narrativa "como o negativo da verdade". Desse modo, a morte aparece como imagem da sociedade, como visão alegórica do progresso e da cultura enquanto coisas amorfas e "atos falhos". ${ }^{46} \mathrm{Se}$ o progresso e a cultura se apresentam em Kafka em suas tendências amorfas é porque sua escrita se apega às "inverdades sociais" para construir seu próprio conhecimento. Esse conhecimento tenta apreender uma galeria de subjetividades em "estado bruto", pois não há progresso sem desumanização. Isso quer dizer que a cultura e o progresso em seu desenvolvimento devem ser entendidos como a imagem de uma sociedade que deixa em seus indivíduos a marca do estigma.O estigma repousa justamente na expressão alemã Abffalsprodukten que se constitui como uma das categorias fundamentais da leitura adorniana de Kafka. A alegoria kafkiana é entendida aqui como a busca dos "refugos sociais" (uma aproximação que Adorno faz entre Kafka e Freud) deixados pelo capitalismo como sistema de produção. Os "refugos sociais" mostram o processo de desmascaramento "da cultura e do indivíduo burguês". 47

Para Adorno, o significado da alegoria do caçador Graco é a impossibilidade de se "morrer em idade avançada, após ter vivido plenamente". ${ }^{48}$ Essa alegoria é algo profundamente infame para a postura relaxante do burguês em seus espaços autoafirmadores, de sua "fachada acolhedora" e sua "consciência alienada" diante da morte. O sonho burguês da "reclusão" enquanto comportamento que reúne "isolamento" e "individuação" se transforma num pesadelo nos cenários kafkianos como podemos observar na seguinte passagem do conto:

Estou estendido num catre de madeira, visto - não é um prazer me contemplar - uma mortalha suja; o cabelo e a barba, grisalhos e pretos, emaranham-se mutuamente; minhas pernas estão cobertas por uma grande manta feminina, de seda, estampada de flores, de franjas longas. ${ }^{49}$

Ainda nessa perspectiva, podemos afirmar que Graco é a própria alegoria de uma morte que perdeu sua significação no mundo dos vivos, banida, por assim dizer, de sua comunicabilidade, pois ela não consegue alçar vôo em direção ao que até então era o seu direito mais sagrado, a transcendência. Sem o direito à transcendência, Kafka faz

\footnotetext{
${ }^{46}$ ADORNO,T.W. “Anotações sobre Kafka”, em:Prismas: crítica cultural e sociedade; tradução: Augustin Wernet e Jorge M. B. de Almeida. São Paulo: Ática, 1998, p. 246-247.

${ }^{47}$ Adorno, p. 247

${ }^{48}$ Adorno, p. 257.

${ }^{49}$ Graco, p. 70.
} 
então muitas referências negativas ao corpo, pois o corpo em si mesmo já é uma referência "cambiante" e "falha". 50

Por isso o caçador Graco não grita "pedindo ajuda", é aquele que não se exalta com as crenças metafísicas, pois a "ajuda" (Hilfe) não pode vir nem da religiosidade judaica e tampouco do cristianismo.

\begin{abstract}
Ninguém vai ler o que aqui escrevo, ninguém virá me ajudar; se fosse colocada como tarefa me ajudar; todas as portas de todas as casas, todas as janelas ficariam fechadas, todas as pessoas permaneceriam em suas camas, as cobertas puxadas sobre as cabeças, a Terra inteira um albergue noturno. Faz sentido, pois ninguém sabe de mim; e, se soubesse de mim, não saberia do meu paradeiro e sendo assim não saberia como me reter ali, não saberia como me ajudar. $O$ pensamento de querer me ajudar é uma doença e deve ser curada na cama. Disso eu tenho consciência e por isso não grito pedindo ajuda, mesmo que, por momento - exaltado como estou, como agora, por exemplo -, pense muito a sério em fazê-lo. Mas sem dúvida basta, para expulsar esses pensamentos, olhar ao meu redor e tomar ciência de onde estou e - posso com certeza afirmá-lo - onde habito faz séculos. 51
\end{abstract}

Essa morte não se ritualiza no ideal judaico, já que a morte para o judeu é a morte do indivíduo que nunca deixou de ser uma figuração pela "vida", representada no indivíduo que soube que sua existência foi regida por uma "comunidade de sangue" e pela "transmissão de geração em geração". ${ }^{52}$ Essa interdição com o judaísmo não o conduz, entretanto, para o ritual da morte cristã. A morte é para o cristão a figuração de uma "via", um rito de passagem da existência pagã para o "tornar-se um cristão"e que se condensa na velha máxima de Tertuliano de que diz: "não nascemos cristão, tornamonos cristãos". 53

Não é de admirar que essas interdições tenham inaugurado no pensamento ocidental, desde a filosofia de Franz Rosenzweig, em A estrela da redenção, uma "teologia filosofante", ou seja, a constatação de que não existe uma ordenação previamente estabelecida ou garantida entre "Deus, mundo, homem", onde o homem reconhece o estágio da "alma só", condição importante para se reconhecer na "incompletude do mundo". ${ }^{54}$ Nessa incompletude, o velho e errante barco de Graco se transforma no testemunho do fracasso da transcendência e que pode ser também

\footnotetext{
${ }^{50}$ PELBART, Peter Pál. "O corpo, a vida, a morte”, em: Kafka e Foucault, sem medos. PASSETTI, Edson (org.). Cotia, São Paulo: Atelie Editorial, 2004, p. 142.

${ }^{51}$ Graco, p. 72.

${ }^{52}$ Cf. RICOEUR, Paul. Nas fronteiras da filosofia; tradução: Nicolás Nyimi Campanário. São Paulo: Loyola, 1996, p.64.

${ }^{53}$ RICOEUR, p.64.

${ }^{54}$ RICOEUR, p. 78.
} 
traduzido, segundo Anders, na compreensão de que só se pode falar em além kafkiano na medida em que ele se transforma em algo essencialmente mundano, de natureza tão precária que sua face só pode mesmo ser transformada em Aquém. ${ }^{55}$

Estou sempre na grande escada que leva para o alto - respondeu o caçador. - Fico dando voltas por essa escadaria infinitamenteampla, ora para cima, ora para baixo, ora à direita, ora à esquerda, sempre em movimento. $\mathrm{O}$ caçador tornou-se borboleta (...)

- Estou sempre em movimento. Mas, se tomo o impulso e lá em cima já se ilumina para mim o portal, acordo no meu velho barco, encalhado em alguma água terrena desolado. ${ }^{56}$

Com efeito, o mundo do aquém evidencia as próprias relações alienantes dos homens no mundo moderno. Se os "objetos ou aparelhos" assumem em Kafka o papel de estranhos heróis é porque o homem é a "mera coisa". ${ }^{57}$ Sob este ponto de vista, dirá Anders, é pertinente pensar em Kafka a partir de uma aproximação filosófica com Marx, no sentido de mostrar o caráter fetichista da mercadoria. Segundo Anders:

Kafka tirou essa ilação. Foi o primeiro. Ou pelo menos quase o primeiro. Teve um antecessor. 'A mesa' - consta num livro famoso - 'transforma-se numa coisa sensorialmente supra-sensível. Não se apóia mais nos pés sobre o chão, mas se firma sobre a cabeça e desdobra, no seu crânio de madeira, caprichos muito mais prodigiosos do que se começasse espontaneamente a dançar'. Não, não é Odradek de Kafka. Nem um objeto de Tieck, Poe ou Gogol, mas a mesa transformada em mercadoria no quarto parágrafo do capítulo primeiro da primeira parte, livro primeiro, do capital de Marx . ${ }^{58}$

Assim, o mundo de Kafka se encontra hermeticamente fechado para as "paisagens belas", pois é a própria alienação que vai se transformando numa "natureza morta".Mas é em função da morte que o narrador kafkiano procura "a neutralização do tempo". Como bem distingue Anders, a neutralização do tempo já estava presente nos modelos "classicistas". Mas estes pensavam a neutralização como forma de eternizar este próprio tempo. Kafka, ao contrário, segue a neutralização do tempo como uma forma de "maldição". "Essa maldição temporal se transfigura, entretanto, na "inconclusividade" narrativa e se constituirá como a maior "virtude" do narrador kafkiano.Com efeito, essa maldição temporal cria em Kafka um sentimento de dúvida: a que paraíso deveria o narrador pertencer? Como essa questão é insolúvel, a expulsão do paraíso se configura como algo constante, mas ao mesmo tempo, isso cria uma "fome de redenção" 60

\footnotetext{
${ }^{55}$ ANDERS, Günter. Op. cit, p. 29.

${ }^{56}$ Graco, p. 70.

${ }^{57}$ ANDERS, Günter. Op. cit, p. 19.

${ }^{58}$ ANDERS, p. 20.

${ }^{59}$ ANDERS, p.74.

${ }^{60}$ ANDERS, p. 124
} 
É justamente esse problema da redenção kafkiana que pretendemos analisar agora, dividido em três momentos: no primeiro, buscamos uma aproximação filosófica da figura do caçador Graco com as reflexões kierkegaardianas que expõem as tensões e desespero do indivíduo como "cavaleiro da fé"; no segundo, abordamos a recepção da filosofia de Nietzsche na escrita kafkiana, aproximando a morte do caçador Graco com a temática da compaixão e, finalmente, traçamos um interlúdio desse conto com as análises de Benjamin sobre as transformações sociais da morte no capitalismo através dos interiores burgueses.

\section{O DECLÍNIO DA MORTE SOLENEE ACRÍTICA AO INTERIOR BURGUÊS: KAFKA E BENJAMIN.}

O sentimento de desconforto e até mesmo de vergonha em relação à morte pode também ser encontrado no pensamento de Walter Benjamin. Na obra Infância Berlinense, Walter Benjamin descreve no fragmento Notícia de uma morte que sua memória reteve, quando criança, a imagem do seu "quarto" e de sua "cama". ${ }^{134} \mathrm{O}$ "quarto" (Zimmer) e a "cama" (Bett) da criança são a representação do ambiente do "bom sono", da infância "feliz", do pequeno paraíso de segurança familiar e, diga-se de passagem, da segurança interior de uma criança de origem burguesa.

Nesse mesmo fragmento, aparece uma visitante inesperada que adentra o quarto da criança: é amorte que, por ironia, traz como seu mensageiro justamente a figura protetora do pai que precisa comunicar, de maneira embaraçosa e sob o motivo aparente de um "ataque cardíaco", a morte de um "de seus primos". ${ }^{135}$ A morte é exposta por Benjamin como uma presença que perturba o interior da própria existência como podemos perceber na seguinte passagem: "fixei na memória meu quarto e minha cama, do mesmo modo como alguém grava com mais precisão um lugar, sentindo que deverá voltar a ele algum dia a fim de buscar algo esquecido". ${ }^{136}$

O que provoca profundas ressonâncias na memória da criança, além da atitude protetora do pai em anunciar a morte do primo como um acontecimento distante e até banal, é o conteúdo implícito da morte como um tema associado ao proibido (já que

\footnotetext{
${ }^{134}$ BENJAMIN, W. "Infância berlinense por volta de 1900", em: Obras Escolhidas v. II; tradução: Rubens Rodrigues T. Filho e José Carlos M. Barbosa. São Paulo: Brasiliense, 1987, v. II, pp. 89-90.

${ }^{135}$ BENJAMIN, p.89-90.

${ }^{136}$ BENJAMIN, p. 90.
} 
verdadeiramente o primo morrera de sífilis) e nada nobre, enfim, da morte como um não lugar e, por isso, a fixação da criança pelo "quarto" e pela "cama" enquanto metáforas que servem para ressaltar muito mais a ausência e o esquecimento social da morte.

Neste caso, a "notícia de uma morte" é assimilada como um "choque". Mas ela é também a alegoria do desconhecimento da criança em relação aos perigos da vida social e sexual, por isso o silêncio do pai - que não conta uma parte importante da notícia, isto é, do primo que morreu de sífilis. Essa omissão feita pelo pai protetor traduz um comportamento não apenas familiar, mas também o desconforto e a forte vergonha social em falar da morte: vergonha, principalmente, da questão sobre do quê se morre, isto é, da morte pelos motivos da pobreza e, no caso do primo, dos perigosos apelos da sexualidade (neste caso das ruas e das prostitutas) que revelavam o próprio reverso da máscara que ocultava a felicidade dos burgueses. ${ }^{137}$

Mas, afinal, o que é essa "segurança burguesa" (bürgerlicheSicherheit) que Benjamin descreve? Podemos encontrar uma explicitação desse tema no fragmento Blumeshof, 12. Novamente, a criança perspicaz e criativa que, sempre transforma os esconderijos na parte predileta da casa, observa que as mobílias são objetos/esconderijos que despertam uma realidade onírica nos burgueses. Cada mobília tinha mesmo a função de fazer um burguês sonhar com o futuro. Essa necessidade de adornar o ambiente com mobílias era a fiel tradução da suposta "serenidade" burguesa diante de um mundo inóspito. Essa prática decorativa expulsava qualquer detalhe que lembrasse o rosto da morte.

A miséria não tinha vez naqueles aposentos, nem mesmo a morte. Neles não havia lugar algum para morrer; por isso é que seus moradores morriam em sanatórios, mas a mobília, já na primeira linha de herdeiros, foi parar nas mãos de comerciantes. A morte não fora prevista para eles. Por isso, durante o dia, aqueles recintos pareciam tão aconchegantes e, à noite, tornavam-se o cenário de pesadelos. ${ }^{138}$

Esse pesadelo é mostrado também no fragmento A Febre. Se a chegada do "infortúnio" (Missgeschick) era percebida pela criança como a imagem de um hábil hóspede que entra sem chamar atenção, com "firme delicadeza" e "paciência" no quarto do doente ${ }^{139}$ os burgueses, por sua vez, tinham a percepção da morte como um hábil

\footnotetext{
${ }^{137}$ CHAVES, E. No Limiar do moderno. Belém-Pará: Paka-Tatu, 2003, pp. 141-142.

${ }^{138}$ BENJAMIN, W. Op. cit, p. 96.

${ }^{139}$ BENJAMIN, W. Berliner Kindheit um Neunzehnhundert.GesammelteSchriften IV1.Suhrkamptaschenbuchwissenschaft.Frankfurt amMain, 1991.p.269. Cf. "Infância berlinense por volta
} 
visitante que se aloja no leito do moribundo, com a diferença de que sua presença devesse ser evitada a qualquer custo.

A criança assimila a doença com "uma consciência limpa" "140, consciência essa que se traduzia na brincadeira infantil do jogo das sombras. Era uma forma infantil de tirar proveito do infortúnio, quando a criança enferma transformava a pálida iluminação do quarto num jogo entre luz e sombra, num divertimento que se inscrevia na parede com silhuetas que assumiam várias formas.

Tirava proveito de meu repouso e da proximidade da parede para saudar a luz com silhuetas. Agora se repetiam no papel da parede todos os jogos que eu fizera com os dedos, jogos ainda mais indefinidos, mais imponentes, mais enigmáticos. Em vez de temer as sombras da noite - assim dizia meu livro de jogos - as crianças alegres as usam como divertimento. ${ }^{141}$

É interessante notar nesta passagem que em seu "leito de doente" a criança estabelece uma proximidade com as "sombras", com a "noite", com as "silhuetas", para transformá-las em jogos "indefinidos" e "enigmáticos”. Certamente, essa passagem nos remete às pesquisas que destacam no pensamento de Benjamin o "território da infância" como "experiências do limiar", experiência infantil que acolhe justamente o desconhecido, o "porvir", a "indeterminação"142 e porque não dizer com a própria experiência da criança com o limiar da morte: a brincadeira com a outra "margem da noite" como descreve Benjamin. ${ }^{143}$

Este fragmento extraído do pensamento de Walter Benjamin nos remete ainda ao problema histórico exposto por Ariès da constatação da perda da familiaridade do adulto em relação à morte, seja porque na vida moderna são tomados todos os cuidados "para afastar as crianças das coisas da morte", ${ }^{144}$ seja porque "cada vez se morre menos em casa e cada vez mais no hospital". ${ }^{145}$ No conto $O$ caçador Gracoencontramostambém uma cena problemática neste sentido. Os ajudantes colocam o morto em direção à parede e acendem "algumas velas compridas", o propósito desse gesto é iluminar o

de 1900"; tradução: Rubens Rodrigues Torres Filho e José Carlos Martins Barbosa, em: Obras escolhidas, v. II. São Paulo: Brasiliense, 1987, p.107.

${ }^{140}$ BENJAMIN ,W. "Infância berlinense por volta de 1900", em: Obras escolhidas, v. II, pp.107-111.

${ }^{141}$ BENJAMIN, pp.111.

${ }^{142}$ GAGNEBIN, J.M. Entre a vida e a morte. Colóquio sobre o Limiar, Belo Horizonte, 22.11.2008 (versão mimeo.), p. 5.

${ }^{143}$ BENJAMIN ,W. Infância berlinense por volta de 1900, Op.cit, p. 108.

${ }^{144}$ ARIÈS,P. História da morte no ocidente. Op.cit, p. 35.

${ }^{145}$ ARIÈS, p. 240. 
ambiente, produzir alguma silhueta, alguma proximidade, algum comentário sobre o morto, um comentário, diga-se de passagem, que ninguém faz.

Sendo assim, se a morte não desperta mais o sentimento da compaixão o que resta ainda dela? No universo kafkiano a compaixão foi substituída pelo sentimento de "acanhamento" em relação à presença dos mortos. No fundo os vivos se sentem "embaraçados", "constrangidos", "não sabem" exatamente "o que fazer" diante de um morto. ${ }^{146} \mathrm{Se}$ em outras épocas, a morte era compreendida como a cena que ressaltava a despedida e o "caráter público da agonia e do luto" e que afirmava, como bem mostram as análises de Ariès, ${ }^{147}$ o lugar "das grandes afeições" por um morto, no conto $O$ caçador Graco encontramos, inversamente, um velório sem amigos", ${ }^{148}$ um morto solitário, uma morte sem dramatizações ou, melhor dizendo, a comicidade de um morto que também é vivo, que não consegue mais morrer.

O ritual do luto é substituído por uma cena caricatural, porque se desenrola sem o "trágico", "sem grandeza" e, como mostra Gagnebin, "não comove nem toca ninguém" ${ }^{149}$. O que se testemunha no conto é o diálogo do prefeito de Riva (uma autoridade bem educada) com um morto-vivo, onde o que se pode extrair desse diálogo é a boa intenção do prefeito de como ele deve proceder para se livrar logo do morto, esse que não passa de um estorvo burocrático (pois já que não morre, não se tem como classificá-lo), ele só atrapalha ${ }^{150}$ porque como diz o prefeito de Riva - com a "testa franzida" - ele "não tem parte alguma no Além". ${ }^{151}$

Com este cenário Kafka também nos mostra que na modernidade a morte foi expulsa do espaço interior que reunia ao mesmo tempo a "autoridade soberana" e o "caráter de solenidade pública" da morte. ${ }^{152}$ Sem nenhuma luz interior, digamos assim, o caçador Graco mostra a morte dentro de um espaço depurado, expulsa de qualquer tipo de psicologização religiosa ou de qualquer caráter pedagógico, pois se a morte tinha ainda uma vinculação com a "transcendência" - morrer sabiamente, por exemplo, - em Graco, encontramos a ausência total de sabedoria.

\footnotetext{
${ }^{146}$ GAGNEBIN, J.M. Entre a vida e a morte, p. 8.

${ }^{147}$ ARIÈS,P. Op.cit, p. 281.

${ }^{148}$ ARIÈS, p. 281.

${ }^{149}$ GAGNEBIN, J.M. Entre a vida e a morte, p. 8-9.

${ }^{150}$ GAGNEBIN, p. 8-9.

${ }^{151}$ Graco, p. 70.

${ }^{152}$ ARIÈS, P. Op. cit., p.234-235.
} 
Os transportadores estavam ocupados em pôr em pé e acender, na cabeceira do esquife, algumas velas compridas, mas com isso não se fez luz; a única coisa que se conseguiu foi que as sombras, que antes estavam quietas, ficassem agitadas, bruxuleando sobre as paredes (...) Ali jazia um homem de cabelo e barca selvagemente revoltos, pele bronzeada, semelhante talvez a um caçador. Esta imóvel, aparentemente sem respirar, de olhos cerrados, embora só o meio ambiente desse a entender que talvez fosse um morto. ${ }^{153}$

As velas "bruxuleando sobre as paredes" mostram no conto do caçador Graco que é inútil o esforço dos ajudantes funerários em querer iluminar o quarto de um morto com "algumas velas cumpridas". A expressão que contraria o gesto dos ajudantes diz: "mas com isso não se fez luz" (aberLichtentstanddadurchnicht). Este cenário, onde o caçador Graco se encontra "aparentemente sem respirar", "de olhos cerrados", envolto em sombras (Schatten) parece mostrar o "não-lugar"do morto.

Sobre essa categoria do não-lugar (entendida como a negatividade) é interessante seguir aqui algumas pistas deixadas pelo filósofo italiano Giorgio Agamben. Em seu livro A linguagem e a morte, Agamben nos lembra, a partir da filosofia de Aristóteles, que apenas o "homem, entre os viventes, possui a linguagem". Este acontecimento - ao mesmo tempo natural e político - tem o seu preço, pois o "homem como vivente e falante" tem uma linguagem que vai abrindo as brechas para as questões do "indizível", que surge cindida numa "voz" que apreende o "indício de dor e de prazer". ${ }^{154}$ Essas duas sensações nos remetem as dimensões cambiante e ética da linguagem porque entra em contato direto com um mundo "negativo", a "abissalidade" das coisas e o risco "mortal do nada". Mas o que chama atenção é o fato de que essa voz cindida mostra que "dor e prazer" se estabelecem dentro de um princípio de reciprocidade entre os seres "viventes e falantes", já que isso nos remete também às questões do "bem e do mal", do "justo e do injusto", ou seja, do próprio modo como esse animal vivente e falante habita a cidade. ${ }^{155}$ Essa realidade do "não-lugar" está presente no conto do caçador Graco, porém, como algo intimamente associado ao problema da perda dessa reciprocidade dos homens com a dor, de uma perda de significação ética da morte.

Ir ao fundo nessa morada da "negatividade" foi para Kafka uma de suas tarefas primordiais. A partir dela, ele inventou um observatório social dos seres em estado de hibridez e de exílio, dos interiores degradados, dos sonhos degenerados. Mas a principal

\footnotetext{
${ }^{153}$ Graco, p. 68.

${ }^{154}$ AGAMBEN, Giorgio. A linguagem e a morte; tradução de Henrique Burigo. Belo Horizonte: Editora UFMG, 2006, p. 126.

${ }^{155}$ AGAMBEN, p. 67.
} 
constatação que a escritura kafkiana podia fazer desse observatório é que o "mito da interioridade" chegou ao fim. ${ }^{156}$

Por isso, nesses tipos sociais que vivem e se expressam sob essas "formas de falência", como dirá Benjamin, estaria incluído também a personalidade e o comportamento do burguês, já que este não estaria livre da agonia provocada pela consciência da morte e que se anuncia nos objetos que perderam sua "utilidade". Esse conteúdo literário presente nos textos de Kafka foi registrado por Benjamin pela seguinte indagação:

Por que o olhar lançado através de janelas desconhecidas sempre recai sobre uma família à mesa durante uma refeição, ou sobre um homem solitário sentado à mesa, sob a lâmpada que pende do teto, ocupado com coisas misteriosamente nulas? Tal olhar é a célula primeva da obra de Kafka. ${ }^{157}$

Esta citação de Benjamin que encontramos no livro das Passagens se refere ao tipo de contemplação kafkiana. Esta contemplação é feita através de "janelas" que filtram a "solidão" e as "coisas misteriosamente nulas" e, talvez, somente com este olhar podemos entender o espírito da modernidade. Trata-se como analisa Rochlitz, de "salvar um passado ameaçado, de fazer ouvir as vozes abafadas da história sem as quais não se poderia ter uma humanidade reconciliada". ${ }^{158}$ Assim as coisas nulas têm um segredo. Este segredo para Benjamin se encontra nas histórias grotescas e, na galeria kafkiana do grotesco, não poderia faltar à família burguesa e seus interiores.

A morte, com efeito, já não pertence mais a um conteúdo religioso, onde a noção de eternidade (Ewigkeit) seria, por exemplo, a idéia predominante, mas seu conteúdo foi afetado profundamente pelas novas forças sociais de produção capitalista. Historicamente, morrer e narrar constituíam atos de uma "consciência coletiva" (Gemeinbewusstsein), ${ }^{159}$ onde podíamos encontrar na voz de um moribundo os fios narrativos que teciam a vida de uma comunidade.

Contudo, Benjamin chega à conclusão de que houve uma transformação no "rosto da morte" (GesichtdesTodes), ${ }^{160}$ entendida a partir do aparecimento das práticas

\footnotetext{
${ }^{156}$ ROCHLITZ, R. O desencantamento da arte: a filosofia de W. Benjamin. S. Paulo: EDUSC, 2003, p. 13.

${ }^{157}$ BENJAMIN, W. Passagens, BOLLE, W. (org.). Tradução: Irene Aron e Cleonice P. B. Mourão. Belo Horizonte: EDUFMG; São Paulo: Imprensa Oficial, 2006, p. 253.

${ }^{158}$ ROCHLITZ, R. Op. cit, p. 15.

${ }^{159}$ BENJAMIN, W. 1985, p. 207.

${ }^{160}$ BENJAMIN, p. 207.
} 
higiênicas nas sociedades burguesas, que com seus "espaços depurados", esvaziaram a morte enquanto espetáculo público de sabedoria coletiva.Podemos avançar um pouco mais nesta análise histórica da transformação do rosto da morte, como diz Benjamin, se seguirmos também as análises posteriores de Ariès. Pois ao contrário do burguês que ostentava sua futilidade como um "sedutor", o homem medieval tinha a consciência coletiva da morte. Essa consciência se traduzia no direito do moribundo, ou seja, o direito de ser advertido sobre a sua própria morte, pois: "Não se morre sem se ter tido tempo de saber que se vai morrer" ${ }^{161}$ Com isso, o quarto do moribundo constituía o próprio cenário da morte enquanto "cerimônia pública". O moribundo tinha o direito de morrer sob os olhos de espectadores e essa "familiaridade" com os mortos implicava numa "concepção coletiva da destinação". Ariès chama atenção para o fato de que a morte em seu sentido coletivo só podia mesmo ser pensada dentro de uma mentalidade fortemente marcada pela socialização. ${ }^{162}$

Com efeito, o moribundo precisava morrer sob advertência, isto é, ter a consciência do tempo derradeiro, o que requer preparativos, preparativos que evitem justamente uma morte na solidão. Morrer era um ato que exigia do moribundo a liberação de um rito, ou seja, o rito que entrelaça ao mesmo tempo a morte com a sabedoria coletiva. ${ }^{163}$

Para Benjamin, entretanto, o burguês é descrito no livro das Passagens, especificamente no caderno $I$, como aquele que de todo não aboliu a velha concepção medieval da "fortificação". Essa antiga arquitetura que serviu de proteção contra o mundo exterior adquiriu formas de "compartimento"; onde as mobílias, em particular, se transformaram em um mundo "habitável". Mas as mobílias evocam um passado ainda mais primitivo, a realidade "totêmica" da relação do homem com os seus objetos. No caso do burguês, a mobília é um totem protetor contra a morte. ${ }^{164}$ Neste aspecto, o interior foi um estilo, a máscara social burguesa no século XIX contra a morte.

Na obraTotem e Tabu, Freud afirmou em que o homem primitivo ainda é nosso contemporâneo. ${ }^{165}$ Foram os burgueses que povoaram o mundo ao seu redor com mobílias que assumiam a fisionomia de seres espirituais, numa tentativa que gerou um

\footnotetext{
${ }^{161}$ ARIÈS, Philippe. História da morte no Ocidente; tradução: Priscila Viana de Siqueira. Rio de Janeiro: Ediouro, 2003, p.p. 27.

${ }^{162}$ ARIÈS, p. 46.

${ }^{163}$ ARIÈS, p. 31.

${ }^{164}$ BENJAMIN, W. Passagens, 2006, p. 247.

${ }^{165}$ FREUD, S. Totem e Tabu; tradução: Óziron Carneiro Muniz. Rio de Janeiro: Imago, 1974.
} 
sistema interior marcado pela necessidade de controlar o mundo exterior. As mobílias se tornaram também "representações oníricas", em "sombras", em "imagens no espelho", mas como qualquer totemismo elas se autotransformaram em demônios, em seres terríveis que também mostram que a assimilação burguesa da morte é um ato falho, uma "forma degradada da superstição". 166

Aqui vale lembrar uma importante frase do caçador Graco: "O erro fundamental da minha morte naquela época gira por meu camarote". ${ }^{167}$ Essa frase do caçador Graco é dita no instante em que ele estava pronto para tomar impulso nas amplas escadas do além, mas sempre acorda em seu velho barco encalhado em águas terrenas. Esse pobre caçador nutre a ilusão de que em seu "camarote" pode despertar alguma teatralidade para o seu luto, mesmo que seja para sua própria contemplação; que ainda pode decorar seu caixão solitário para atravessar o "portal" do além. Essa cena nos faz lembrar, ironicamente, que a cultura do "camarote" foi o que os burgueses do século XIX e do início do século XX desenvolveram como um sistema mimético bastante particular para expulsar a presença da morte de seus aposentos, de seus interiores. Expliquemos melhor estas idéias.

No caderno I das Passagens, intitulado "O interieur, o Rastro", Benjamin oferece imagens preciosas para entendermos a significação do interior burguês no âmbito da literatura, da arquitetura e da psicanálise a partir de várias anotações, citações e esboços de estudos sobre a modernidade. Benjamin descreve, por exemplo, o ano de 1830 como o triunfo do romantismo na literatura e na arquitetura. ${ }^{168}$ Mas podemos perceber com essa descrição o quanto de excentricidade esse romantismo oferece, já que o seu apego sentimental é direcionado para o "mobiliário" - o que mostra o cenário de um romantismo solitário e desumanizado.

Esse gosto burguês foi também direcionado para a decoração das fachadas (um gosto que associava o apego à exibição e à fantasia), assim como, para o uso de cortinas decoradas por "imagens femininas" exóticas, sensuais e, preferencialmente, de mulheres orientais. Em ambos os casos, o interior burguês era, sobretudo, uma "paisagem de fantasia", uma arquitetura - como destaca Hessel - que associava intimamente a

\footnotetext{
${ }^{166}$ Freud, pp. 92-94.

${ }^{167}$ Graco, p. 70.

${ }^{168}$ Cf. W. Benjamin Passagens, p. 274, ver notas de estudo da obra de E. Levasseur, Histoiredes Classes Ouvrièreset de l' industrie em France de 1780 às 1870, Paris, 1904, v. II, pp. 206-207.
} 
mobília e o sonho. ${ }^{169}$ Mas do mesmo como o sonho se desliga do sonhador quando este desperta, a mobília se desliga também de seu proprietário, revelando o quanto a sua pretensa soberania de posse dos objetos podia ser deposta pelo tempo.

Assim, o "espaço se disfarça". ${ }^{170}$ Com essa expressão Benjamin identifica nos interiores burgueses um tipo de comportamento mimético. $\mathrm{O}$ elemento mais antigo da prática mimética sempre foi o comportamento de proteção, de fuga ou de paralisação do sujeito diante de um perigo exterior. Talvez não seja difícil imaginar que o mimetismo não se deixou representar apenas como prática do medo experimentada no próprio corpo, ora assumindo formas de identificação com o inimigo e com o horror, ora assumindo imagens automutiladas ou de aniquilamento, mas também com práticas que remontam a "história primeva" do habitar humano. Existe em todo habitar formas miméticas onde o sujeito não apenas se fixa como também se deixa assimilar profundamente pelo ambiente. Em todo caso, esse habitar pela mimesis não deixa de ser também um comportamento que evita a proximidade com qualquer indício ou signo da morte.

Com efeito, o habitar passa a ser também uma extensão mimética do próprio corpo ou, para ser mais preciso, escreve Benjamin, "o reflexo da estada do homem no ventre materno". ${ }^{171}$ Foi a busca idealizada desse "ventre materno" diante de um mundo exterior hostil que empurrou as práticas miméticas para um certo modelo de conhecimento da arquitetura e de suas práticas "decorativas". Podemos dizer que se o mimetismo primitivo se baseava em práticas mágicas, o mimetismo burguês se baseia no encantamento do interior da moradia. O mago foi substituído pelo morador. Segundo Benjamin, a "forma mais extrema" desse estranho e moderno mimetismo foi o "modo de existência do século XIX". ${ }^{172}$

O homem primitivo percebeu que podia transformar os objetos da natureza em acessórios para si mesmo e, com isso, criar um "casulo", para se encaixar perfeitamente num mundo cada vez mais inóspito, já que "num casulo" o ambiente "traz a impressão

\footnotetext{
${ }^{169}$ BENJAMIN, W. Passagens, p. 248.

${ }^{170}$ Benjamin, p. 251.

${ }^{171}$ Benjamin, p. 255.

${ }^{172}$ Benjamin, p. 255.
} 
de seu morador". ${ }^{173}$ Já no século XIX, os burgueses transformaram todo habitar em formas de "estojo".

Não existe um só objeto para o qual o século XIX não tenha inventado um estojo. Para relógios de bolso, chinelos, porta-ovos, termômetros, baralhos - e, na falta de objetos: capas, protetoras, passadeiras, cobertas e guarda-pós". ${ }^{174}$

Na consciência primitiva, o ato mimético de afugentar ou adiar a presença da morte consistia na paralisação, na passividade que se assemelha ao próprio semblante da morte, que se confundia com ela em sua não-identidade. Já a consciência burguesa, com sua pretensa identidade "extravagante" e "decorativa", criou um espaço interior em que a própria morte não pode ser filtrada, pois a morte, acreditava o burguês, era um estado puramente psicológico; contra ela era preciso criar "estados de ânimo" mais refinados que eram seus aposentos.

Viver dentro deles era como ter se enredado numa teia de aranha espessa, urdida por nós mesmos, na qual os acontecimentos do mundo ficam suspensos, esparsos, como corpos de insetos ressecados. Esta é a toca que não queremos abandonar. ${ }^{175}$

Por isso mesmo Benjamin ressalta que o novo "niilismo" se encontra no "aconchego burguês", decorado "com o nada", "com o trivial", "com o banal" . ${ }^{176}$ Aliás, foi Marx que salientou que a concepção do "além" foi modificada pelo "domicílio" burguês. Se este domicílio assume para o proletariado a imagem de um novo "além" sob o "céu de suas riquezas", ${ }^{177}$ para o burguês ele assume um espaço de alienação, uma espécie de retorno à velha "caverna" para se proteger de um mundo hostil. Advém daí seu gosto pelas tapeçarias - tecidas pelas mais finas fantasias, e pelo Oriente, com a sua "suave brisa" e que trazia consigo toda a "magia da intimidade". ${ }^{178}$

Foi esse estranho "além", digamos assim, composto pela alma depuradora do burguês, que fez Baudelaire também descrever esses interiores em seu Spleen de Paris. Diz o poeta: "Os crepúsculos que dão cores tão ricas à sala de jantar ou ao salão são

\footnotetext{
${ }^{173}$ Benjamin, p. 255.

${ }^{174}$ Benjamin, p. 255.

${ }^{175}$ Benjamin, p. 251.

${ }^{176}$ BENJAMIN, W. Passagens, Op. cit., p.248.

${ }^{177}$ MARX, K. Der historische Materialismus, ed. org. por LANDSHUT e MAYER, Leipzig, 1932, vol. I, p. 325, citadopor BENJAMIN, W., Passagens, Op. cit, p. 258.

${ }^{178}$ Passagens, p. 247.
} 
filtrados por belos tecidos ou por estas janelas altas". ${ }^{179}$ Filtrar o seu mundo. Eis, portanto, a técnica do burguês com seus interiores. Daí ser perfeitamente compreensível seu apego incondicional a "pelúcia", que segundo Benjamin, "é a matéria na qual se imprimem mais facilmente os rastros".Isso justifica que tenha surgido nesse período uma indústria refinada e especializada na produção desses materiais, cuja concepção principal seria o de reduzir o mundo em figurações de "bibelôs" e "estatuárias". Nesse mundo de rastros - instalado como um ateliê- era quase natural que surgissem "grupos de Cupidos e de Bacantes"; ${ }^{180}$ em cada compartimento, essas figuras mitológicas inspiram a odisséia particular do burguês.

Sabemos, por outro lado, que Kafka conhecia como ninguém as técnicas dos artistas expressionistas que costumavam brincar com as transfigurações do semblante das Górgonas na modernidade e que associavam petrificação e beleza. Esse semblante das Górgonas, especialmente a representação da cabeça de Medusa, se constituirá depois da I Guerra Mundial como um tema de crítica social ao suposto mundo de segurança burguesa que costumava se apropriar caseiramente dos objetos artísticos, transformando-as em máscaras de luxo. Por isso mesmo, os artistas expressionistas precisavam acentuar os traços de um sentimento social, marcado pela desproteção total e pela liberação de expressões de horror, medo e espanto no mundo. ${ }^{181}$

Para Benjamin, os interiores burgueses usurparam um elemento social que de todo não era estranho ao conteúdo da morte: o pânico. Esse sentimento não deve ser concebido como uma petrificação negativa. Existe um instante no pânico que revela as imagens inversas da máscara social burguesa da felicidade e do progresso.

Esse "belo horror", como dirá Benjamin, retoma uma tensão revolucionária, um reencontro entre o "pânico" e a "festa", pois ambos, "irmãos separados por longo tempo", ${ }^{182}$ mostram que o catastrófico e o lúdico nos fazem estremecer, que apuram e incendeiam nosso olhar em direção a um horizonte (da história) sempre diferente, como "um golpe de vento" que "põe a descoberto o forro escarlate da capa" de nossa

\footnotetext{
${ }^{179}$ BAUDELAIRE, C. L' invitation au voyage, Le Spleen de Paris, Ed. Simon, Paris, p.27. Citado por BENJAMIN, W., Op. cit, p. 259.

${ }^{180}$ BENJAMIN, W. Passagens, Op. cit., p. 251.

${ }^{181}$ ANDERS, G. Op. cit., pp.142-143.

${ }^{182}$ BENJAMIN, W. Imagens do pensamento, tradução: Rubens Rodrigues Torres Filho e José Carlos Martins Barbosa, em: Obras escolhidas, v. II. São Paulo: Brasiliense, 1987, p. 273-274.
} 
existência. ${ }^{183}$ Por isso o pânico guarda secreta e inconscientemente um desejo de alegria e de insurreição e é também uma resistência a uma ordem repetitiva das coisas, pois o pânico é o semblante do inabitual,a imagem que mais ruboriza o semblante do colecionador burguês em seu gosto de depuração que almeja apenas destacar o "valor funcional ou utilitário" dos objetos.

A prática social da depuração se vincula ao desejo burguês da aniquilação dos rastros da morte como algo semelhante à aniquilação de uma sujeira. A descrição desse fenômeno, tanto em Benjamin quanto em Kafka, ganhará profunda atualidade se pensarmos que essa prática higiênica se legitimou ulteriormente como sistema social totalitário, que avançou ferozmente contra as supostas “vidas indesejáveis" dos judeus nos campos de concentração nazista.

Esse ato de não saber-morrer ou esta errância do morto Graco nos leva, certamente, a um problema ético fundamental no texto kafkiano: a temática dos sobreviventes. A morte e os seus desdobramentos, como luto e trauma, mostra a incapacidade (ou o recalque) do sujeito moderno em elaborar "simbolicamente", na "alma" e no "corpo", a relação entre luto e palavra. Aqui podemos afirmar que esta incapacidade de morrer é uma representação fiel dos sobreviventes, principalmente por não poderem fechar suas feridas e pela dificuldade de encontrar seus ouvintes, pois,

...depois das duas Guerras mundiais e, sobretudo, depois da Shoah, a temática do trauma torna-se predominante na reflexão sobre a memória. Ao que parece, as feridas dos sobreviventes continuam abertas, não podem ser curadas nem por encantações nem por narrativas. A ferida não cicatriza e o viajante, quando, por sorte, consegue voltar para alguma pátria, não encontra palavras para narrar nem ouvintes dispostos a escutá-lo. ${ }^{184}$

\footnotetext{
${ }^{183}$ BENJAMIN, p. 274.

${ }^{184}$ GAGNEBIN, J.M. Lembrar, escrever, esquecer. São Paulo: Editora 34, 2006, p.110.
} 